\title{
Drought Screening and Supplemental Irrigation Management for some Rice Cultivars in Drought Prone Area of Bangladesh
}

\author{
M.H. $\operatorname{Ali}^{1}$ \\ ${ }^{1}$ Agricultural Engineering Division, Bangladesh Institute of Nuclear Agriculture, Bangladesh \\ Correspondence: M.H. Ali, Agricultural Engineering Division, Bangladesh Institute of Nuclear Agriculture, \\ Mymensingh-2202, Bangladesh. Tel: 0088-01818-4865-34.
}

Received: December 3, 2018; Accepted: December 28, 2018; Published: December 31, 2018

\begin{abstract}
Water stress is one of the limiting factors for rice production. Under rainfed condition with erratic rainfall, water stress becomes a serious threat for sustainable rice production. Drought tolerant cultivars along with appropriate management practices can solve the problem. Field and control condition studies were carried out to study the response of some rice cultivars to water-stress, and to develop appropriate on-farm management strategy for sustainable yield under drought condition. The results revealed that most of the cultivars produced good yield under drought condition compared to normal irrigated condition (under control condition and field study). Levee management strategy (of height of $20 \mathrm{~cm}$ ) seems a viable option to alleviate the effect of drought under field condition. Levee management and life-support supplemental irrigation (when necessary) can facilitate good yield of most of the cultivars. These cultivars seemed to be appropriate for cultivation in drought-prone areas.
\end{abstract}

Keywords: rice, drought stress, supplemental irrigation, levee management

\section{Introduction}

Water stress is the main limiting factor for cereal crop production worldwide. Water resources are becoming scarce day by day (Kuper et al. 2017, Cullet and Stephan 2016). This is also true for Bangladesh (Sadia and Ali 2016, Sarkar et al., 2013). In Bangladesh, water supply heavily depends on rivers originating from neighbor countries and rainfall. Climate change, deforestation and construction of dams in common rivers have contributed to enter a reduced amount of water (Ali, 2010a). As surface water supply is decreasing day by day, irrigation pressure is going towards groundwater resource. But this resource is not unlimited. Intensive crop cultivation (irrigated) during dry season have contributed to excessive groundwater withdrawal of many parts of Bangladesh (Asraf and Ali, 2015; Ali et al., 2012). There are many areas where irrigation facility could not be implemented. The northwestern part of Bangladesh, the Barind Tract area, receives a low annual rainfall than that of the other regions of the country. Crop production in such areas depends on natural rainfall. In addition, changing pattern of rainfall (frequency, amount and its distribution) imposes drought in crop growing period. Research results showed that increase in temperature can increase crop water demand (Ali et al., 2007).

Rice is the main staple food grain in Bangladesh. During 2016-17, total rice production (Boro, Aus and Aman) of the country is about 3,3804,000 Metric ton (BBS, 2017). Due to continuous increase in population, increased amount of rice should be produced and hence, there is a great need for sustainable rice production. In this context, a solution lies between development of drought tolerant rice variety and sustainable irrigation supply system.

In Bangladesh, rice grows in main three seasons: Boro (Jan.- May), Aus (April - July), and Aman (Aug.-Nov.). In Boro season, production of rice depends on irrigation (from surface or groundwater). In Aus and Aman season, the water demand is mostly meet by natural rainfall. Supplemental irrigation is needed for uneven or little rainfall, or during a long dry-spell. Drought sensitive cultivar can suffer from soil moisture in such a period. Drought tolerant cultivars can mitigate the impact of drought. Another possibility is to capture rainwater in the rice plot by maintaining sufficient height levee, which can facilitate plants to maintain turgor during long dry-spell or drought.

Both In Vitro and In situ screening of rice cultivars have been practiced (Sabesan and Saravanan, 2016; Kumar et al., 2015). Different indices to screen rice for drought resistance have been used by different researchers. These include drought resistance as estimated from grain yield, visual scoring, canopy-temperature based indices, and uprooting force (Zou et al., 2007; Ingram et al., 1990; Kumar et al., 2015). From a detail review, Ingram et al. (1990) concluded that visual scoring was the best method. In case, controlled water deficit can not be imposed, drought resistance may be estimated by measuring both uprooting force and grain yield. Gomathinayagam et al. 
(1998) noted that drought SES scores of susceptible and resistant checks from pot screening were significantly correlated with average scores from field drought tolerance trial results in the IRRI data bank. Zou et al. (2007) concluded that drought resistance can be identified by measuring yield potential, delay in flowering, or drought response index under drought stress and normal irrigated condition.

The effects of water-stress (or drought) on plant growth processes, and adaptation strategies by plants have been studied and documented by numerous researchers (Arnon, 1975; Clark and Hiller, 1973; Turner, 1986; Andersen and Aremu, 1991; Neumann et al., 1994; Yang et al., 2001; Ali 2010b; Sikuku et al., 2010). But the ultimate signature of water stress reflects on grain yield. Sikuku et al. (2010) investigated the effects of water deficit on physiology and morphology of three varieties of NERICA rainfed rice in the field and green house. They imposed treatments as: irrigating once in a day (control), after every 2 days, 4 days and 6 days, respectively. They found that water deficit causes reduction in plant growth and biomass accumulation. Among the three varieties, NERICA 2 was the most tolerant in terms of plant growth. Yang (2007) used soil-water potential value to schedule irrigation for rice. The level of soil moisture content has also been used to schedule irrigation by other researchers (Ali and Talukder, 2001).

Alam and Mondal (2003) reported that continuous 3-7 cm standing water $\left(T_{1}\right)$ required the highest amount of water followed by $7 \mathrm{~cm}$ irrigation water application after disappearing of standing water $\left(\mathrm{T}_{2}\right)$ and $7 \mathrm{~cm}$ standing irrigation water application 3 days after disappearing of standing water $\left(\mathrm{T}_{3}\right)$ treatments. The highest water productivity was found in treatment $\mathrm{T} 3$ followed by $\mathrm{T}_{2}$ and $\mathrm{T}_{\mathrm{I}}$. They concluded that, maintaining continuous standing water in the hybrid rice fields is not necessary for optimum yield. Rather, application of irrigation water 3 days after standing water disappeared from the field could be practiced for obtaining optimum yield of hybrid rice, with minimum water application.

The effects of drought stress on final product, that is yield, and the frequency of supplemental irrigation requirement under rainfed rice depends on the soil type, cultivar (maturity period, drought resistance capacity), ET demand, and rainfall availability at the field site (Ali, 2010b, Ali et al., 2014). Thus, it is not appropriate to make definite recommendation regarding the number and amount of irrigation to be applied for all cultivars.

Therefore, the present experiment was designed to: (1) Study the response of cultivars to water-stress, (2) Determine the critical stage(s) of the cultivars to water-stress (if any), and (3) Develop appropriate supplemental irrigation management strategy of some newly developed rice mutants/cultivars for higher yield and water productivity.

\section{Materials and Methods}

\subsection{Location, Soil and Climatic Condition of the Site}

Experiments were conducted in Field and in control condition. The details are as follows:

\begin{tabular}{|c|c|c|c|}
\hline Year & Season & Pot (Location), & (Location) \\
\hline 2015 & $\begin{array}{l}\text { Aman } \\
\text { (July - Oct.) }\end{array}$ & - & $\begin{array}{l}\text { a) Nachol Upazila }\left(24^{0} 44^{\prime \prime} \mathrm{N}, 88^{0} 24^{\prime \prime} \mathrm{E}\right) \\
\text { b) Chapainawabganj Sadar }\left(24^{\circ} 40^{\prime \prime} \mathrm{N}, 88^{0} 18^{\prime \prime} \mathrm{E}\right)\end{array}$ \\
\hline 2016 & $\begin{array}{l}\text { Aus } \\
\text { (April - July) }\end{array}$ & $\begin{array}{l}\text { Mymensingh } \\
\left(24^{0} 43^{\prime \prime} \mathrm{N}, 90^{0} 26^{\prime \prime} \mathrm{E}\right)\end{array}$ & $\begin{array}{l}\text { a) Nachol Upazila } \\
\text { b)Tanor Upazila }\left(24^{0} 40^{\prime \prime} \mathrm{N}, 88^{0} 31^{\prime \prime} \mathrm{E}\right)\end{array}$ \\
\hline
\end{tabular}

The local climate at the field site is sub-humid and sub-tropic with summer dominant rainfall. The average annual rainfall (1991-2015) at the field experimental site is about $1450 \mathrm{~mm}$, mostly concentrated over the months of April to September (monsoon period). The topography is flat and high land. Texturally the soil is silt loam with bulk density ranging from 1.2 to $1.3 \mathrm{gm} / \mathrm{cm}^{3}$.

\subsection{Experimental Details}

\subsection{Pot Experiment for Drought Screening (At Mymensingh): Aus Season}

The objectives were: (1)To study the response of cultivars to water-stress, (2) To determine the critical stage(s) of the cultivars to water-stress. The experiment was conducted in large container/pot $(1.5 \mathrm{~m} \times 1.0 \mathrm{~m} \times 0.35 \mathrm{~m}$, having drainage outlet, and rain-shed over it) at Field Lysimeter Complex of 'Bangladesh Institute of Nuclear Agriculture' (BINA), Mymensingh, Bangladesh.

The scheduled treatments were: $T_{1}=$ Control (normal irrigation, 3 days AWD); $T_{2}=$ Irrigation when available soil moisture (ASM) within the root zone drops below $60 \%$ (throughout the growing season); $\mathrm{T}_{3}=$ Irrigation during 
booting to soft-dough stage, if ASM drops below $60 \%$ and normal irrigation for the rest period; $\mathrm{T}_{4}=$ Irrigation when ASM drops below 75\% (throughout the growing season). $\mathrm{T}_{5}=$ Irrigation when ASM drops below $85 \%$ (prior to booting stage), and from booting to soft-dough stage at 75\% ASM.

The cultivars were: V1 $=\mathrm{N}_{4} / 350 / \mathrm{P}-4(5), \mathrm{V} 2=\mathrm{N}_{10} / 350 / \mathrm{P}-5-4, \mathrm{~V} 3=\mathrm{N}_{4} / 250 / \mathrm{P}-2(6)-26, \mathrm{~V} 4=$ Binadhan-17, V5 = BRRI dhan 48 (as Check).

Note: The mutant lines V1 to V4 were derived from NERICA Rice through mutation breeding. Recently, the mutant line $\mathrm{N}_{10} / 350 / \mathrm{P}-5-4$ (V2) has been certified/released by National Seed Board (NSB) as Binadhan-21, for cultivation in Aus season throughout the country.

Two series of container ( 2 replicates) were used. The design was RCBD, with split-plot. The experimental soil was fertilized with the 2.5 times recommended doses for field soil (of Urea @215 kg/ha, TSP@180 kg/ha and MP@100 kg/ha). The seedlings (28 days old) were transplanted on $29^{\text {th }}$ April, and harvested during $31^{\text {st }} \mathrm{July}-7^{\text {th }}$ Aug., 2016.

Treatments were imposed accordingly. The grain weight was adjusted to $12 \%$ moisture following Ali (2010c).

2.2 Field Experiment: Supplemental Irrigation and Levee Management in Aus and Aman Rice in Drought Prone Area

The Objective were: (a) To study the response of cultivars to water stress, and (b) To develop appropriate irrigation management strategy along with levee management for higher water productivity. The design was Randomized Complete Block, with split-plot arrangement of the treatments. The main-plot treatments (Levee and supplemental irrigation management) differed slightly between Aus and Aman season, as follows:

\begin{tabular}{|c|c|}
\hline Aus season & Aman season \\
\hline $\begin{array}{l}\mathrm{T}_{1}=\text { normal levee (farmer's practice, } 10 \sim 12 \mathrm{~cm} \text { ) and } \\
\text { supplemental irrigation ( throughout the growing } \\
\text { season) when available soil-moisture (ASM) within } \\
\text { the root zone drops below } 55 \% \\
\mathrm{~T}_{2}=20 \mathrm{~cm} \text { height levee around the plot, and rainfed } \\
\mathrm{T}_{3}=20 \mathrm{~cm} \text { height levee around the plot, and } \\
\text { supplemental irrigation during booting to soft-dough, } \\
\text { if ASM drops below } 55 \% \\
\mathrm{~T}_{4}=20 \mathrm{~cm} \text { height levee around the plot, and } \\
\text { supplemental irrigation during booting to soft-dough, } \\
\text { if PASM drops below } 75 \% \text {. } \\
\mathrm{T}_{5}=\text { Control (normal irrigation, } 3 \text { days AWD) }\end{array}$ & $\begin{array}{l}\mathrm{T}_{1}=\text { normal levee (farmer's practice) and } \\
\text { supplemental irrigation ( throughout the growing } \\
\text { season) when ASM drops below 55\%; } \\
\mathrm{T}_{2}=20 \mathrm{~cm} \text { height levee around the plot, and rainfed; } \\
\mathrm{T}_{3}=20 \mathrm{~cm} \text { height levee around the plot, and } \\
\text { supplemental irrigation during booting to soft-dough, } \\
\text { if ASM drops below } 55 \% \text {. } \\
\mathrm{T}_{4}=\text { Control (farmer's practice: rainfed, and normal } \\
\text { levee, } 10 \mathrm{~cm} \text { ); }\end{array}$ \\
\hline
\end{tabular}

The treatments were made little different based on the natural rainfall/drought pattern of the two seasons. In Aus season, there is scanty of rainfall, and thus natural severe drought may be possible.

\section{The sub-plot treatments (Cultivars):}

There were little variations of cultivars between Aus and Aman season, as follows:

\begin{tabular}{lll}
\hline $\begin{array}{l}\text { Aman season (2015) } \\
\text { Field }\end{array}$ & $\begin{array}{l}\text { Aus season (2016) } \\
\text { Pot }\end{array}$ & $\begin{array}{l}\text { Aus season (2016) } \\
\text { Field }\end{array}$ \\
\hline $\mathrm{V} 1=\mathrm{N}_{4} / 350 / \mathrm{P}-4(5)$ & $\mathrm{V} 1=\mathrm{N}_{4} / 350 / \mathrm{P}-4(5)$ & $\mathrm{V} 1=\mathrm{N}_{4} / 350 / \mathrm{P}-4(5)$ \\
$\mathrm{V} 2=\mathrm{N}_{10} / 350 / \mathrm{P}-5-4$ & $\mathrm{~V} 2=\mathrm{N}_{10} / 350 / \mathrm{P}-5-4$ & $\mathrm{~V} 2=\mathrm{N}_{10} / 350 / \mathrm{P}-5-4$ \\
$\mathrm{~V} 3=\mathrm{N}_{4} / 250 / \mathrm{P}-2(6)-26$ & $\mathrm{~V} 3=\mathrm{N}_{4} / 250 / \mathrm{P}-2(6)-26$ & V3 $=$ NERICA-4 \\
$\mathrm{V} 4=$ Binadhan-17 & V4 $=$ Binadhan-17 & V4 = Binadhan-17 \\
$\mathrm{V} 5=\mathrm{BRRI}$ dhan 56 & V5 $=$ BRRI dhan 48 & V5 $=$ BRRI dhan 48 \\
V6 $=\mathrm{N}_{4} / 250 / \mathrm{P}-1(2)$. & (as Check). & (as Check). \\
\hline
\end{tabular}

The cultivar V5 was changed between Aman and Aus season due to their appropriateness (recommended) in that season. 


\subsection{Soil Moisture Measurement}

Soil moisture in the container/pot was measured using handy 'Digital soil moisture meter' (model: rapidest, Custon Manufacturing, China) and gravimetric method.

\subsection{Irrigation Water Productivity}

Irrigation water productivity (IWP) was calculated as (Ali, 2017):

$$
\mathrm{IWP}=\frac{Y_{\text {grain }}}{I}
$$

Where $\mathrm{Y}_{\text {grain }}$ is the grain yield, $\mathrm{I}$ is the irrigation amount.

\subsection{Analysis of Experimental Data}

The analysis of variance technique (ANOVA) was carried out on the on yield attributes and yield data as applicable to the design. The significance of the treatment effect was determined using F-test at $5 \%$ probability level, and to determine the significant difference among the means of the treatments, least significant difference (LSD) or Tukey's Honest Significant Difference was estimated (using statistical software "STAR", developed by International Rice Research Institute (IRRI)).

\section{Results and Discussion}

\subsection{Year 2015}

\subsubsection{Field Experiment: Aman Season}

The seedlings were transplanted on 29 July, 2015 and harvested during 15 - 22 Oct., 2015. Supplemental irrigation did not require in this season.

The mean rice yield under different treatments (irrespective of cultivars) are presented in Table 1.1. The levee management treatments showed insignificant yield difference, while the cultivars showed significant difference. Although the treatment effects are insignificant, the levee managements have positive effect on grain yield (T2, T3). The levee $\times$ cultivar (interactions) showed insignificant yield difference (not shown).

\section{Cultivar yield}

In general, higher yield was obtained at Chapai Sadar compared to Nachol location. This may be due soil condition and climatic variation. At Chapai Sadar location, the highest yield was obtained in cultivar V5, which is statistically similar with V1 and V4. Similarly, the cultivars V2, V3 and V6 are statistically similar (but lower yield than the earliers).

At Nachol location, the highest yield was obtained in cultivar V4 followed by V5. The cultivars V2, V3 and V6 produced statistically similar yield.

Table 1.1 Mean effects of treatments (irrigation and cultivars) on grain yield

\begin{tabular}{lll}
\hline $\begin{array}{l}\text { Irrigation } \\
\text { management }\end{array}$ & $\begin{array}{l}\text { Grain yield }\left(\mathbf{t ~ h a}^{-\mathbf{1}}\right) \\
\text { Chapai Sadar }\end{array}$ & Nachol \\
$\mathrm{T}_{1}$ & 5.00 & 3.69 \\
$\mathrm{~T}_{2}$ & 5.31 & 4.00 \\
$\mathrm{~T}_{3}$ & 5.17 & 4.06 \\
$\mathrm{~T}_{4}$ & 4.91 & 3.62 \\
$T H S D_{(0.05)}$ & $\mathrm{NS}$ & $\mathrm{NS}$ \\
\hline Cultivars & & \\
\hline $\mathrm{V}_{1}$ & $5.62 \mathrm{a}$ & $3.16 \mathrm{~d}$ \\
$\mathrm{~V}_{2}$ & $4.48 \mathrm{~b}$ & $3.41 \mathrm{~cd}$ \\
$\mathrm{~V}_{3}$ & $4.13 \mathrm{~b}$ & $3.39 \mathrm{~cd}$ \\
$\mathrm{~V}_{4}$ & $5.67 \mathrm{a}$ & $4.94 \mathrm{a}$ \\
$\mathrm{V}_{5}$ & $6.29 \mathrm{a}$ & $4.25 \mathrm{~b}$ \\
$\mathrm{~V}_{6}$ & $4.44 \mathrm{~b}$ & $3.96 \mathrm{bc}$ \\
$\mathrm{THSD}_{(0.05)}$ & & \\
\hline
\end{tabular}

Note: THSD $=$ Tukeys's Honest Significant Difference. 
Means with the same letter are not significantly (statistically) different at $5 \%$ level of probability by THSD test.

\subsection{Year 2016}

\subsubsection{Field Experiment - Aus Season}

The seedlings (28 days old) were transplanted on 27 April, 2016 and harvested on 27 July, 2016. Normal irrigation (common for all) was applied up to 28 days from transplanting. Then the treatments were imposed.

\section{A - Nachol location (Chapai Nawabgonj): Aus}

The rainfall distribution during the crop period is shown in Fig.2.1. The common irrigation amount (including land preparation) was $25 \mathrm{~cm}$. The mean yield under different treatments and interaction effects are presented in Table 2.1 and Table 2.2, respectively. The irrigation amount and frequency under different treatments are presented in Table 2.3.

The levee and irrigation management treatments, and irrigation $\times$ cultivar showed insignificant yield difference, while the cultivars showed significant difference. Normal irrigation (4 nos.), rainfed (only 01 life irrigation) and soil moisture basis irrigation (55 and 75\% depletion of ASM - 02 and 01 frequency) showed insignificant yield difference, indicating that the cultivars have the capability to produce good yield under water-stress condition. The cultivar V1 produced the highest yield for all irrigation management conditions $(6.0-6.4 \mathrm{t} / \mathrm{ha})$.

When considered the irrigation water savings compared to normal irrigation (T5), the stressed treatments saved 25 $-39 \%$ water with insignificant yield reduction.

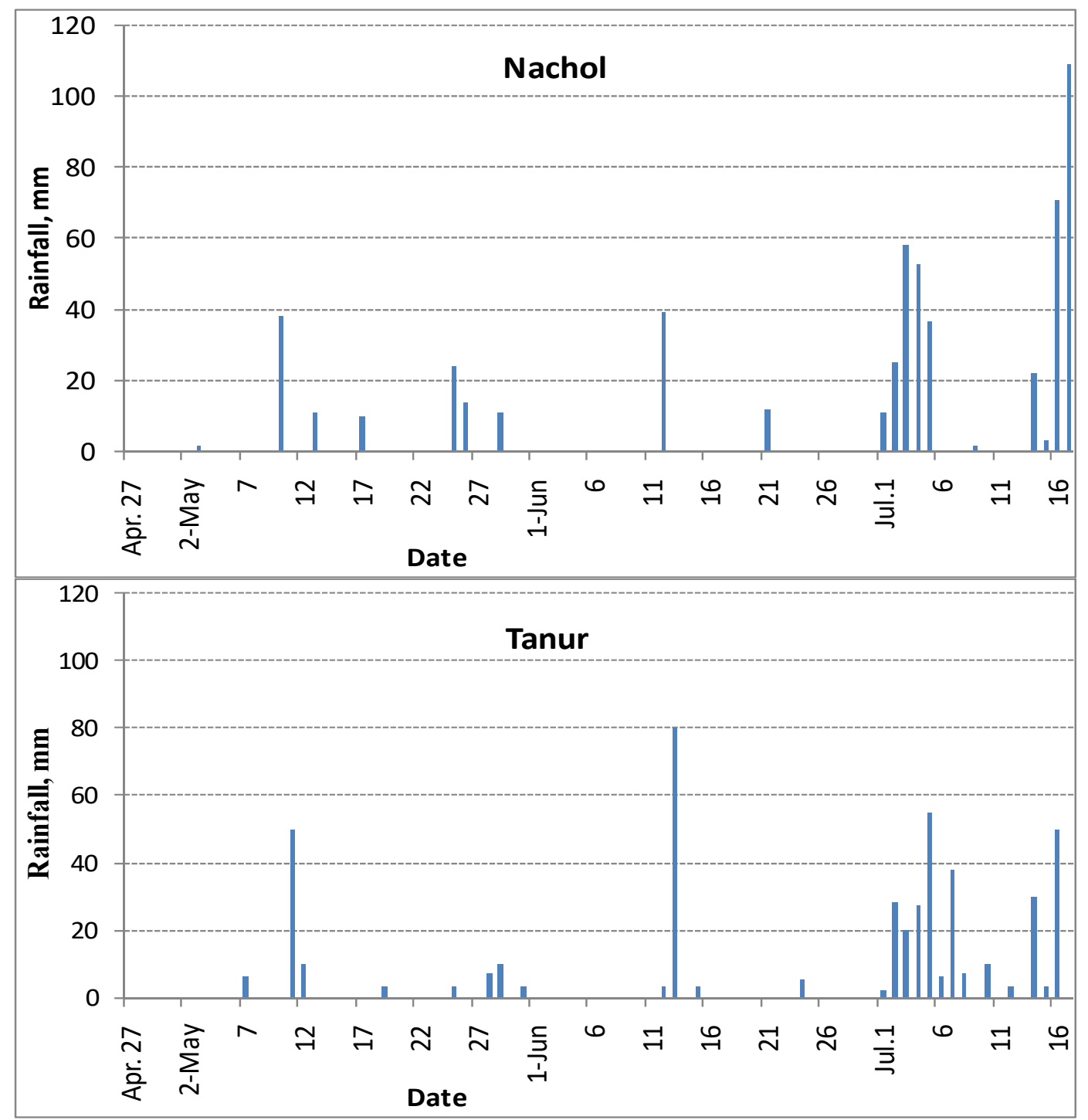

Figure 2.1 Rainfall distribution during crop period 
Table 2.1 Mean effects of treatments (irrigation and cultivars) on grain yield at Nachol

\begin{tabular}{ll}
\hline \multicolumn{1}{c}{ Treatments } & Grain yield, $\mathrm{t} \mathrm{ha}^{-1}$ \\
\hline $\mathrm{T}_{1}$ & 4.87 \\
$\mathrm{~T}_{2}$ & 4.87 \\
$\mathrm{~T}_{3}$ & 4.95 \\
$\mathrm{~T}_{4}$ & 4.91 \\
$\mathrm{~T}_{5}$ & 5.05 \\
$F$-test $(5 \%)$ & $\mathbf{N}$ \\
$\mathrm{V}_{1}$ & $6.23 \mathrm{a}$ \\
$\mathrm{V}_{2}$ & $5.73 \mathrm{~b}$ \\
$\mathrm{~V}_{3}$ & $2.47 \mathrm{e}$ \\
$\mathrm{V}_{4}$ & $4.87 \mathrm{~d}$ \\
$\mathrm{~V}_{5}$ & $5.35 \mathrm{c}$ \\
\hline F-test (5\%) & \\
\hline
\end{tabular}

Means with the same letter are not significantly different at \% probability level by Tukeys's Honest Significant Difference (THSD) test.

Table 2.2 Interaction effects of irrigation and cultivars on grain yield $\left(\mathrm{t} \mathrm{ha}^{-1}\right)$

\begin{tabular}{|c|c|c|c|c|c|}
\hline \multirow[t]{2}{*}{ Variety } & \multicolumn{5}{|c|}{ Yield $\left(\mathrm{t} \mathrm{ha}^{-1}\right)$ under different irrigation treatments } \\
\hline & T1 & $\mathrm{T} 2$ & T3 & $\mathrm{T} 4$ & T5 \\
\hline V1 & 6.32 & 6.08 & 6.17 & 6.18 & 6.41 \\
\hline V2 & 5.59 & 5.72 & 5.78 & 5.76 & 5.81 \\
\hline V3 & 2.42 & 2.41 & 2.57 & 2.40 & 2.57 \\
\hline V & 4.78 & 4.81 & 4.87 & 4.88 & 4.99 \\
\hline V5 & 5.23 & 5.33 & 5.38 & 5.35 & 5.45 \\
\hline$F$-test (5\%) & NS & NS & NS & NS & NS \\
\hline
\end{tabular}

Table 2.3 Irrigation frequency, total irrigation and water savings under different treatments

\begin{tabular}{lllllll}
\hline $\begin{array}{l}\text { Irri. } \\
\text { treatment }\end{array}$ & $\begin{array}{l}\text { Common irri. (for } \\
\text { establish), cm }\end{array}$ & $\begin{array}{l}\text { Irri. frequency after } \\
\text { establishment }\end{array}$ & $\begin{array}{l}\text { Applied irrigation } \\
\text { amount }(\mathrm{cm})\end{array}$ & $\begin{array}{l}\text { Total applied } \\
\text { water }(\mathrm{cm})\end{array}$ & $\begin{array}{l}\text { Water } \\
\text { compared to T5 }(\%)\end{array}$ \\
\hline T1 & 25 & 2 & 8 & 33 & 25 \\
T2 & 25 & 1 - life irri. & 2 & 27 & 39 \\
T3 & 25 & 2 & 7 & 32 & 27 \\
T4 & 25 & 1 & 4 & 29 & 34 \\
T5 & 25 & 4 & 19 & 44 & - \\
\hline
\end{tabular}

\section{B: Tanur location (Rajshahi) (Aus)}

The mean yield under different irrigations and varieties is presented in Table 3.1. The irrigation management treatments showed insignificant yield difference, but the cultivars showed significant difference. The cultivar V1 produced the highest yield followed by V5. The interaction effects (yield of the varieties under different levee and irrigations management) are presented in Table 3.2. The interactions are not significant at $5 \%$ probability level. In general, the cultivar V1 produced the highest yield for all irrigation management conditions $\left(4.64-5.38 \mathrm{tha}^{-1}\right)$. Irrigation treatments and interaction effects showed insignificant yield difference, indicating that the cultivars have the capability to produce good yield under water stress condition.

The irrigation amount and frequency under different treatments are presented in Table 3.3. The common irrigation amount (including land preparation) was $20 \mathrm{~cm}$. When considered the irrigation water savings compared to normal irrigation (T5), the stressed treatments saved $25-38 \%$ water with insignificant yield reduction.

At both the locations, the cultivar V1 produced the highest yield; and the cultivars V2, V4 and V5 produced comparable yield. 
Table 3.1 Mean effects of treatments (irrigation and cultivars) on grain yield at Tanur

\begin{tabular}{ll}
\hline \multicolumn{1}{c}{ Treatments } & Grain yield, $\mathrm{t} \mathrm{ha}^{-1}$ \\
\hline $\mathrm{T}_{1}$ & 4.62 \\
$\mathrm{~T}_{2}$ & 4.40 \\
$\mathrm{~T}_{3}$ & 4.80 \\
$\mathrm{~T}_{4}$ & 4.44 \\
$\mathrm{~T}_{5}$ & 4.79 \\
$F$-test (5\%) & $\mathrm{NS}$ \\
$\mathrm{V}_{1}$ & $5.06 \mathrm{a}$ \\
$\mathrm{V}_{2}$ & $4.39 \mathrm{c}$ \\
$\mathrm{V}_{3}$ & $4.34 \mathrm{c}$ \\
$\mathrm{V}_{4}$ & $4.43 \mathrm{c}$ \\
$\mathrm{V}_{5}$ & $4.83 \mathrm{~b}$ \\
$F$-test (5\%) & \\
\hline
\end{tabular}

Means with the same letter are not significantly different by LSD test at $5 \%$ level.

Table 3.2 Interaction effects of irrigation and cultivars on grain yield at Tanur

\begin{tabular}{|c|c|c|c|c|c|}
\hline \multirow[t]{2}{*}{ Variety } & \multicolumn{5}{|c|}{ Yield $\left(\mathrm{t} \mathrm{ha}^{-1}\right)$ under different irrigation treatments } \\
\hline & T1 & $\mathrm{T} 2$ & T3 & T4 & T5 \\
\hline V1 & 5.09 & 4.64 & 5.38 & 4.97 & 5.23 \\
\hline V2 & 4.37 & 4.31 & 4.68 & 4.02 & 4.58 \\
\hline V3 & 4.48 & 4.05 & 4.47 & 4.35 & 4.36 \\
\hline V4 & 4.38 & 4.40 & 4.36 & 4.17 & 4.85 \\
\hline V5 & 4.79 & 4.59 & 5.11 & 4.71 & 4.94 \\
\hline F-test (5\%) & NS & NS & NS & NS & NS \\
\hline
\end{tabular}

Table 3.3 Irrigation frequency, total irrigation and water savings under different treatments

\begin{tabular}{llllll}
\hline $\begin{array}{l}\text { Irri. } \\
\text { treatment }\end{array}$ & $\begin{array}{l}\text { Common irri. (for } \\
\text { establish), } \mathrm{cm}\end{array}$ & $\begin{array}{l}\text { Irri. frequency } \\
\text { establishment }\end{array}$ & $\begin{array}{l}\text { Applied irrigation } \\
\text { amount }(\mathrm{cm})\end{array}$ & $\begin{array}{l}\text { Total applied } \\
\text { water }(\mathrm{cm})\end{array}$ & $\begin{array}{l}\text { Water } \\
\text { compared to T5 (\%) }\end{array}$ \\
\hline T1 & 20 & 2 & 10 & 30 & 25 \\
T2 & 20 & 1 & 5 & 25 & 38 \\
T3 & 20 & 2 & 10 & 28 & 30 \\
T4 & 20 & 1 & 5 & 25 & 38 \\
T5 & 20 & 4 & 20 & 40 & \\
\hline
\end{tabular}

\subsubsection{Pot Experiment - Aus Season, 2016}

The seedlings (28 days old) were transplanted on $29^{\text {th }}$ April, and harvested during $31^{\text {st }}$ July $-7^{\text {th }}$ Aug., 2016.

The mean effects of irrigation treatments and cultivars on yield and yield attributing characters of rice cultivars are summarized in Table 4.1. The cultivars showed significant difference in tiller/plant, seed/panicle and grain yield, while irrigation treatments showed insignificant difference in yield and yield attributing characters. The yield of cultivars under different irrigation regimes is shown in Table 4.2. The cultivars $\mathrm{V}_{1}, \mathrm{~V}_{4}$ and $\mathrm{V}_{5}$ produced good yield under stress condition $\left(\mathrm{T}_{4}\right.$ and $\mathrm{T}_{5}$ ) relative to normal irrigation condition $\left(\mathrm{T}_{1}\right)$, indicating their tolerance capacity under drought (resembled to $12-18$ days dryness).

Table 4.1 Mean effects of irrigation treatments and cultivars on yield and yield attributing characters of rice cultivars

\begin{tabular}{llllll}
\hline Treatment & $\begin{array}{l}\text { Plant height } \\
(\mathrm{cm})\end{array}$ & Tiller/plant & $\begin{array}{l}\text { Panicle } \\
\text { length } \\
(\mathrm{cm})\end{array}$ & seed/panicle & $\begin{array}{l}\text { Grain yield } \\
\left(\mathrm{gm} / \mathrm{m}^{2}\right)\end{array}$ \\
\hline $\mathrm{T}_{1}$ & 85.8 & 9.7 & 24.0 & 87.3 & 401.5 \\
$\mathrm{~T}_{2}$ & 87.4 & 9.6 & 22.7 & 72.0 & 384.0 \\
$\mathrm{~T}_{3}$ & 88.0 & 11.5 & 22.2 & 75.1 & 381.4 \\
\hline
\end{tabular}




\begin{tabular}{llllll}
\hline $\mathrm{T}_{4}$ & 85.4 & 9.7 & 22.4 & 68.3 & 356.4 \\
$\mathrm{~T}_{4}$ & 86.0 & 11.3 & 20.4 & 72.9 & 357.6 \\
F-test (5\%) & $\mathrm{NS}$ & $\mathrm{NS}$ & $\mathrm{NS}$ & $\mathrm{NS}$ & NS \\
Cultivars & & & & & \\
$\mathrm{V}_{1}$ & 91.3 & $12.3 \mathrm{a}$ & 22.1 & $79.8 \mathrm{ab}$ & $424.7 \mathrm{~b}$ \\
$\mathrm{~V}_{2}$ & 75.7 & $10.9 \mathrm{a}$ & 22.4 & $66.0 \mathrm{c}$ & $269.3 \mathrm{c}$ \\
$\mathrm{V}_{3}$ & 81.3 & $5.7 \mathrm{~b}$ & 23.0 & $63.6 \mathrm{c}$ & $270.2 \mathrm{c}$ \\
$\mathrm{V}_{4}$ & 91.2 & $11.4 \mathrm{a}$ & 21.8 & $92.4 \mathrm{a}$ & $493.37 \mathrm{a}$ \\
$\mathrm{V}_{5}$ & 93.1 & $11.6 \mathrm{a}$ & 22.3 & $73.7 \mathrm{bc}$ & $423.4 \mathrm{~b}$ \\
$F$-test(5\%) & $\mathrm{NS}$ & & $\mathrm{NS}$ & & \\
\hline
\end{tabular}

Means with the same letter are not significantly (statistically) different at $5 \%$ probability level by Tukeys's Honest Significant Difference (THSD) test.

Table 4.2 Interaction effects of irrigation treatments and cultivars on grain yield of rice

\begin{tabular}{|c|c|c|c|c|c|}
\hline \multirow[t]{2}{*}{ Treatment } & \multicolumn{5}{|c|}{ Grain yield of different cultivars $\left(\mathrm{gm} / \mathrm{m}^{2}\right)$} \\
\hline & V1 & V2 & V3 & V4 & V5 \\
\hline $\mathrm{T}_{1}$ & 460.8 & 290.5 & 285.5 & 519.5 & 451.4 \\
\hline$T_{2}$ & 417.5 & 292.3 & 263.0 & 517.5 & 454.3 \\
\hline$T_{3}$ & 421.5 & 253.3 & 252.0 & 578.5 & 401.5 \\
\hline $\mathrm{T}_{4}$ & 412.6 & 250.0 & 267.0 & 424.0 & 428.5 \\
\hline $\mathrm{T}_{5}$ & 410.8 & 260.5 & 283.5 & 427.3 & 406.0 \\
\hline$F$-test $(5 \%)$ & NS & NS & NS & NS & NS \\
\hline
\end{tabular}

Table 4.3 Irrigation frequency, total irrigation and water savings under different treatments

\begin{tabular}{llllll}
\hline $\begin{array}{l}\text { Irri. } \\
\text { treatment }\end{array}$ & $\begin{array}{l}\text { Irrigation up to } \\
\text { establishment } \\
\text { (cm) }\end{array}$ & $\begin{array}{l}\text { No. of irrigation } \\
\text { after } \\
\text { started (nos.) }\end{array}$ & $\begin{array}{l}\text { Total } \\
\text { treatment }\end{array}$ & $\begin{array}{l}\text { water savings } \\
\text { irrigation } \\
\text { amount }(\mathrm{cm})\end{array}$ & $\begin{array}{l}\text { Irri. date (days after } \\
\text { T1) }\end{array}$ \\
\hline T1 & 16 & 06 & 44 & - & $32,41,53,61,67,79$ \\
T2 & 16 & 04 & 35 & 20 & $41,53,31,67$ \\
T3 & 16 & 04 & 34 & 23 & $41,51,61,79$ \\
T4 & 16 & 03 & 29 & 34 & $44,53,65$ \\
T5 & 16 & 03 & 30 & 32 & $44,56,67$ \\
\hline
\end{tabular}

\section{Summary and Conclusion}

Rice is the main source of food for more than half of the global population, and nearly $100 \%$ in Bangladesh. Most of the rice cultivars are affected by abiotic stress, specially water stress. Water deficit is the main constraint for rice production under rainfed condition. Drought tolerant cultivars along with appropriate management practices can solve the problem. We carried out field and control condition studies to study the response of some cultivars to water-stress, and to develop appropriate on-farm management strategy for sustainable yield of rice under drought condition. Results showed that most of the cultivars (V1, V4, V5) produced good yield (showed insignificant yield reduction) under drought condition compare to normal irrigated condition. In general, under field condition, levee height of $20 \mathrm{~cm}$ showed positive impact on yield. Levee management and life-support supplemental irrigation (when necessary) can facilitate good yield of several cultivars (V1, V2, V4, V5). These cultivars seemed appropriate for cultivation in drought-prone areas.

\section{References}

Alam, M. M., \& Mondal, M. K. (2003). Comparative water requirements and management practices for hybrid and inbred rice cultivation in Bangladesh. Bangladesh J. Agril. Sci., 30(2), 345-351.

Ali, M. H. (2010a). Introduction - perspectives and general concept of irrigation. In: Fundamentals of Irrigation \& On-farm Water Management, Volume 1. Springer-Verlag, New York, pp. 1-10. https://doi.org/10.1007/978$1-4419-6335-2$

Ali, M. H. (2010b). Plant: An element of water abstraction. In: Fundamentals of Irrigation \& On-farm Water Management, Volume 1. Springer-Verlag, New York, pp. 219-270. https://doi.org/10.1007/978-1-4419- 
$6335-2$

Ali, M. H. (2010c). Crop water requirement and irrigation scheduling. In: Fundamentals of Irrigation \& Onfarm Water Management, 1. Springer-Verlag, New York, pp. 399-453. https://doi.org/10.1007/978-1-44196335-2

Ali, M. H. (2017). Irrigation water management of some salt tolerant rice cultivars for higher yield. Asian J. of Adv. Agril. Research, 3(4), 1-7. https://doi.org/10.9734/AJAAR/2017/35860

Ali, M. H., \& Tulukder, M. S. U. (2001). Methods or approaches of Irrigation Scheduling - An overview. J. of the Institution of Engineers, Bangladesh, 28/AE(1), 11-23.

Ali, M. H., Abustan, I., Zaman, M. H., Islam, A. K. M. R., \& AlBassam, A. (2014). Optimising irrigation water for field crops to maximize the yield and economic return. Global Advanced Research Journal of Agricultural Science, 3(8), 223-232. Retrieved from http:/garj.org/garjas/pdf/2014/August/Ali\%20et\%20al.pdf

Ali, M. H., Adham, A. K. M., \& Rahman, M. (2007). Impact of climate change on crop water demand and its implication on water resources planning. J. Agrometeorol., 9(1), 20-25.

Ali, M. H., Sarkar, A. A., \& Rahman, M. A. (2012). Analysis on groundwater-table declination and quest for sustainable water use in the North-western region (Barind area) of Bangladesh. J. Agril. Sci. and Applications., 1(1), 26-32. https://doi.org/10.14511/jasa.2012.010105

Andersen, M. N., \& Aremu, J. A. (1991). Drought sensitivity, root development and osmotic adjustment in field grown peas. Irri. Sci., 12, 45-51. https://doi.org/10.1007/BF00190708

Arnon, I. (1975). Physiological principles of dry-land crop production. In. Gupta, U.S. (Ed.) Physiological aspects of dry-land farming. Oxford \& IBH Publishing Co., New Delhi, pp. 3-145.

Asraf, T., \& Ali, M. H. (2015). Water-table dynamics and trend in three Upazilas of Rajshahi district (Barind area), Bangladesh. Asian Academic Research Journal of Multidisciplinary, 2(6), 286-310. Retrieved from http://www.asianacademicresearch.org/2015_abstract/november_md_2015/25.pdf

BBS (Bangladesh Bureau of Statistics). (2017). Statistical year book of Bangladesh. Bangladesh Bureau of statistics, Statistics Division, Ministry of planning; Government of the people's Republic of Bangladesh, pp.39.

Clark, R. N., \& Hiller, E. A. (1973). Plant measurements as indicators of crop water deficit. Crop Sci., 13, 466-469. https://doi.org/10.2135/cropsci1973.0011183X001300040022x

Cullet, P., \& Stephan, R. M. (2017). Introduction to 'Groundwater and Climate Change: Multi-level Law and Policy Perspectives. Water International, 42(6), 641-645. https://doi.org/10.1080/02508060.2017.1358960

Gomathinayagam, P., Ingram, K. T., \& Maguling, M. A. (1998). Pot screening for drought tolerance in rice. University Library, Uni. Of the Philippines at Los Banos. Retrieved from http:/www.uplb.edu.ph

Ingram, K. T., Real, J. G., Maguling, M. A., Obien, M. A., \& Loresto, G. C. (1990). Comparison of selection indices to screen lowland rice for drought resistance. Euphytica, 48(3), 253-260. https://doi.org/10.1007/BF00023658

Kumar, S., Dwivedi, S. K., Haris, A. A., Prakash, V. E. D., Mondal, S., \& Sinh, S. K. (2015). J. of AgriSearch, 2(2), 105-111.

Kuper, M., Amichi, H., \& Pierre-Louis, M. (2016). Groundwater use in North Africa as a cautionary tale for climate change adaptation, 725-740. https://doi.org/10.1080/02508060.2017.1351058

Neumann, P. M., \& Azaizen, L. D. (1994). Hardening of root cell walls: A growth inihibitory response to salinity stress. Plant Cell Envt, 17, 303-309. https://doi.org/10.1111/j.1365-3040.1994.tb00296.x

Sabesan, T., \& Saravanan, K. (2016). In Vitro screening of Indica rice genotypes for drought tolerance using polyethylene glycol. Int. J. of Advances in Agril. \& Env. Engg., 3(2), 375-80.

Sadia, M., \& Ali, M. H. (2016). Recent trend of reference evapotranspiration in the north-eastern region of Bangladesh. Journal of Basic and Applied Res. Int., 19(1), 10-19.

Sarkar, A. A., Zaman, M. H., Rahman, M. A., Nain, M. J., Karim, N. M., \& Ali, M. H. (2013). Increasing cropping intensity and profitability in dry Barind area of Bangladesh, utilizing profile soil moisture and supplemental irrigation. Bangladesh J. Nuclear Agric., 27 \& 28, 103-118.

Sikuku, P. A., Netondo, G. W., Onyango, J. C., \& Musymi, D. M. (2010). Effects of water deficit on physiology 
and morphology of three varieties of NERICA rainfed rice. APRN J. of Aril. And Biol. Sci., 5(1), 23-28.

Turner, N. C. (1986). Adaptation to water deficits: a changing perspective. Aust. J. Plant Physiol., 13, 175-190. https://doi.org/10.1071/PP9860175

Yang, J. (2007). Water-Saving and High-Yielding Irrigation for Lowland Rice by Controlling Limiting Values of Soil Water Potential. J. of Integrative Plant Biology, 49(10), 1445-1454. https://doi.org/10.1111/j.16729072.2007.00555.x

Yang, J., Zhang, J., Wang, Z., Zhu, Q., \& Wang, W. (2001). Remobilization of carbon reserves in response to water deficit during grain filling of rice. Field Crop Res., 71, 47-55. https://doi.org/10.1016/S0378-4290(01)001472

Zhang, Y., Kendy, E., Qiang, Y., Changming, L., Yanjun, S., \& Hongyong, S. (2004). Effect of soil water deficit on evapotranspiration, crop yield, and water use efficiency in the North China Plain. Agril. Water Manage., 64, 107-122. https://doi.org/10.1016/S0378-3774(03)00201-4

Zou, G. H., Liu, H. Y., Mei, H. W., \& Liu, G. L. (2007). Screening for drought resistance of rice recombinant inbred populations in the field. J. of Integrative Biology, 49(10), 1508-1516. https://doi.org/10.1111/j.16729072.2007.00560.x

\section{Copyrights}

Copyright for this article is retained by the author(s), with first publication rights granted to the journal.

This is an open-access article distributed under the terms and conditions of the Creative Commons Attribution license (http://creativecommons.org/licenses/by/4.0/). 